\title{
Variability in Content and Chemical Constituents of Essential Oil of Sweet Basil (Ocimum basilicum L.) Obtained from Aerial Plant Parts
}

\author{
Yasmin A. A. Aburigal1, Nada B. Hamza' ${ }^{2}$, Ismail H. Hussein ${ }^{3}$, Elfadl Y. Elmogtaba3, \\ Tanzeil H. Osman ${ }^{4}$, Faiza I. Ali ${ }^{4}$, Awatif A. M. Siribel ${ }^{5}$ \\ ${ }^{1}$ Faculty of Agricultural Sciences, University of Gezira, Wad Medani, Sudan \\ ${ }^{2}$ Commission for Biotechnology and Genetic Engineering, National Center for Research, Khartoum, Sudan \\ ${ }^{3}$ National Oilseeds Processing Research Institute (NOPRI), University of Gezira, Wad Medani, Sudan \\ ${ }^{4}$ Forensic Laboratories, Khartoum, Sudan \\ ${ }^{5}$ Medicinal and Aromatic Plants Research Institute, National Center for Research, Khartoum, Sudan \\ Email: *nada.hamza@gmail.com
}

Received 3 February 2016; accepted 27 March 2016; published 30 March 2016

Copyright (C) 2016 by authors and Scientific Research Publishing Inc.

This work is licensed under the Creative Commons Attribution International License (CC BY). http://creativecommons.org/licenses/by/4.0/

(c) (i) Open Access

\section{Abstract}

Sweet basil (Ocimum basilicum L.) project that is being conducted at the National Oilseed Processing Research Institute (NOPRI) aims at exploiting the genetic diversity and associated phenotypic variation in the investigated basil germplasm and evaluating key factors such as variety, plant ontogeny and plant parts that affect yield, chemical constituents, aroma and flavor of essential oils. This paper discussed the variability inessential oils content and chemical constituents of the aerial plant parts of the basil. An open-air pot experiment was carried out using three accessions provided by Agricultural Research Corporation-Genetic Resources Unit, Sudan. The essential oils were hydro distilled from the aerial parts, flowers, leaves, stems, using Clevenger apparatus. The chemical constituents of the essential oils were determined by Gas Chromatography-Mass Spectrometry (GC-MS). As the hydro distillation yielded no oil from the stem, we present only the results for leaves and flowers. The results revealed that the essential oil content varied with a range of $0.29 \%$ to $0.33 \%$ for flowers and $0.32 \%$ to $0.48 \%$ for leaves. As usual, the content of essential oils was higher in leaves than in flowers. The Silate-Egyptian accession had the lowest essential oil content obtained from leaves and flowers. However, South Darfur accession from Sudan had the highest oil content but did not significantly differ from Kennana accession. Several oil components were identified based upon comparison of their mass spectral data with those of reference compounds published in literature or stored in a computer library. The combined GC-MS

*Corresponding author.

How to cite this paper: Aburigal, Y.A.A., Hamza, N.B., Hussein, I.H., Elmogtaba, E.Y., Osman, T.H., Ali, F.I. and Siribel, A.A.M. (2016) Variability in Content and Chemical Constituents of Essential Oil of Sweet Basil (Ocimum basilicum L.) Obtained from Aerial Plant Parts. Advances in Bioscience and Biotechnology, 7, 183-187. http://dx.doi.org/10.4236/abb.2016.73016 
analysis showed that methyl eugenol was the major constituent of the essential oil of Kennana accession. While the major constituent of essential oil of South-Darfur and Silate-Egyptian accessions were germacrene and linalool, respectively.

\title{
Keywords
}

\author{
Sweat Basil, Ocimum basilicum L., Essential Oils, Hydrodistillation, Plant Parts, Chemical \\ Constituents
}

\section{Introduction}

Recognizing the potential value of traditional medicine for the expansion of health service, the World Health Assembly (WHA) passed a number of resolutions in 1976, 1977, 1979, 1987, and 1988 to draw attention to the potential reserve constituted by traditional practitioners [1]. World Health Organization estimates that $80 \%$ of the population in Africa relies on traditional medicines, mostly plant drugs, for their primary health care necessities [2]. The genus Ocimum is an important member of Lamiaceae family. It is native to tropical and subtropical regions of Africa, Asia, Central and South America [3] [4]. Among the species of the genus, Ocimum basilicum L. (sweet basil) is a perennial, herbaceous aromatic and medicinal plant that widely cultivated in many parts of the world. Basil grows between $30-130 \mathrm{~cm}$ tall, with opposite, light green, silky leaves $3-11 \mathrm{~cm}$ long and 1 - 6 $\mathrm{cm}$ broad. The flowers are small, white in color and arranged in a terminal spike [5]. Manytypes of basil have different aroma because the herb has a number of different essential oils that come together in different proportions for various varieties. Essential oils are highly viscous organic liquids which are extracted from leaves, stems, flowers, roots, herbs, brushes, and trees through distillation [6]. Quantitative and qualitative variability in essential oil is caused by different factors, including genetic and ontogenetic ones. A great differentiation not only in morphological characters of plants, but also in the content and chemical constituents of essential oil of sweet basil was detected [7]. The chemical composition of basil extracts reveals the presence of tanines, flavonoids, saponins, and volatile terpenes like camphor, tymol, methylchavicol, linalool, eugenol, 1-8-cineol and pinenes [8]. Interest in essential oils has increased in recent decades with the popularity of aromatherapy, which claims that essential oils and other aromatic compounds have beneficial health effects. Scientific studies in vitro have established that compounds in basil oil have potent antioxidant, antiviral, and antimicrobial properties, and potential for use in treating cancer [9]-[12]. [13] reported that essential oil of basil showed promising antibacterial and insecticidal activity against crop pest and insects. A preliminary result [14] revealed that essential oils of Sudanese basils are promising as topical repellents at $0.1 \%$ concentration against nocturnal mosquito. Essential oils are also widely used in perfumes, cosmetics, cleaning products and for flavoring of foods and drinks [15]-[17].

In Sudan, basil exists as a wild herb and cultivated for ornamental purposes. Based on the main constituents of the essential oils, [14] classified the Sudanese basil accessions into 7 chemotypes, namely, high methyl-chavicol (>50\%), high linalool (>50\%), high geraniol (>50\%), linalool-methyl cinnamate, linalool-geraniol, methyl cinnamate-linalool and eugenol-linalool. The importance of basil is increasing and has promising future in Sudan. Currently, serious efforts are underway for its cultivation on commercial scales, for export and for the local market, this must be accompanied by a strong research and development program which is what this project is intended to highlight. From the chemical point of view, the essential oil composition frequently changes in different parts of the plant. Knowledge of the essential oil chemotypes is a very important quality criterion for their marketing and contributes to their commercialization as functional ingredients in food technology or in phytopharmacy. The objective of the present study was to identify the chemical constituents as well as determine the contents of the essential oil of the aerial plant parts of sweet basils.

\section{Materials and Methods}

\subsection{Plant Materials}

The three accessions of sweet basil (Kennana, South-Darfur, and Silate) that were used in the study were provided by the Genetic Resources Unit at Agricultural Research Cooperation, Sudan. Seeds were planted in pots 
containing equal volumes of sand: loam at the National Oilseed Processing Research Institute (NOPRI) on February 2014. Each accession was grown in three replicates. Aerial parts of basil plants were collected at the flowering stage on April 2014.

\subsection{Hydro Distillation of Essential Oils}

All above-ground portions were harvested and weighed, and the leaves, flowers, and stems were separated manually from each other and dried under room temperature for 72 hours. For distillation of essential oils, 200 gram of each sample was ground and subjected to hydro distillation for 4 hours using Clevenger apparatus. The

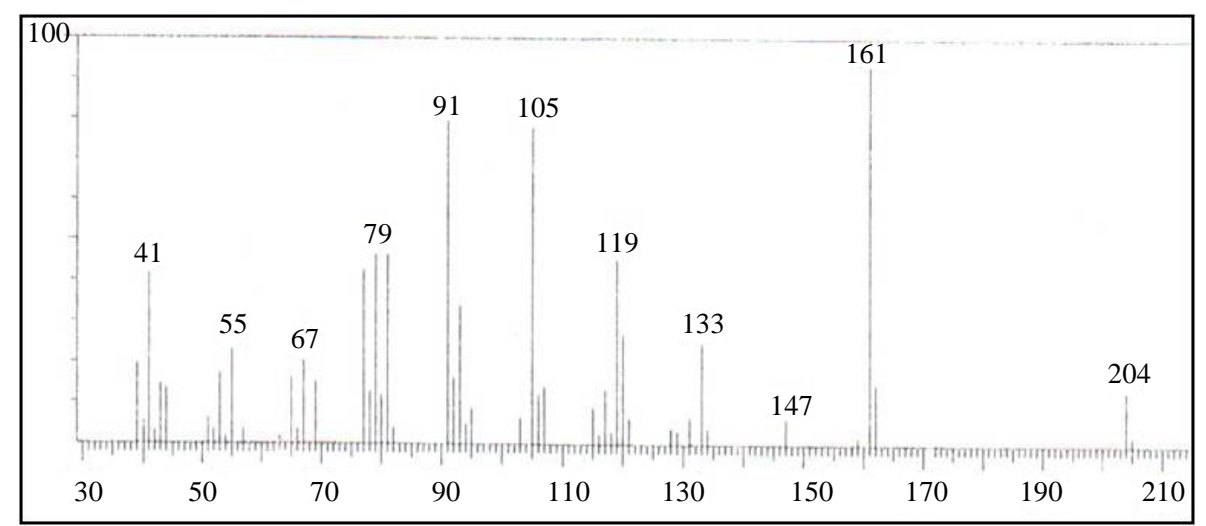

(a)

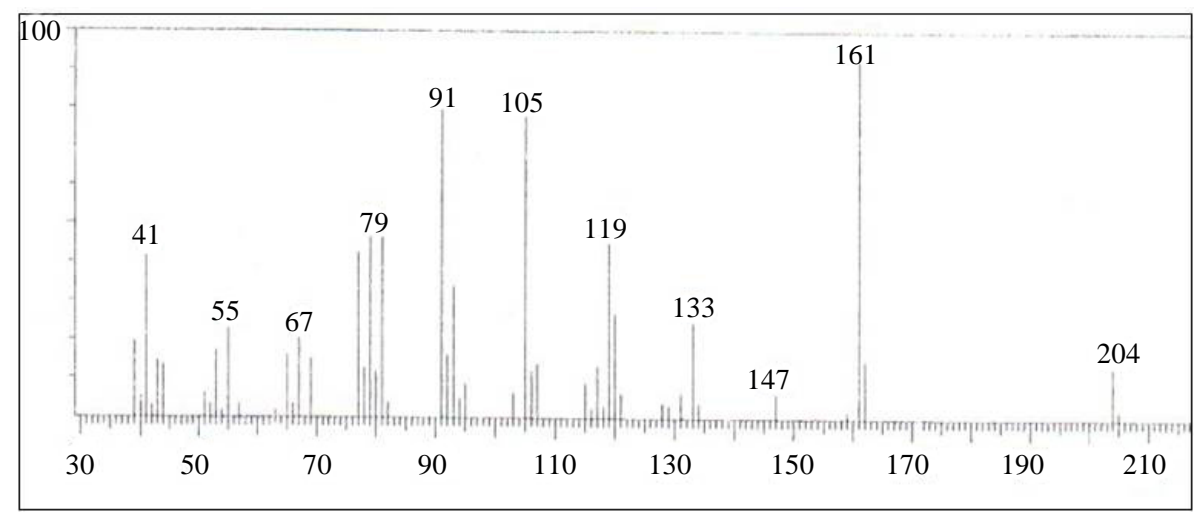

(b)

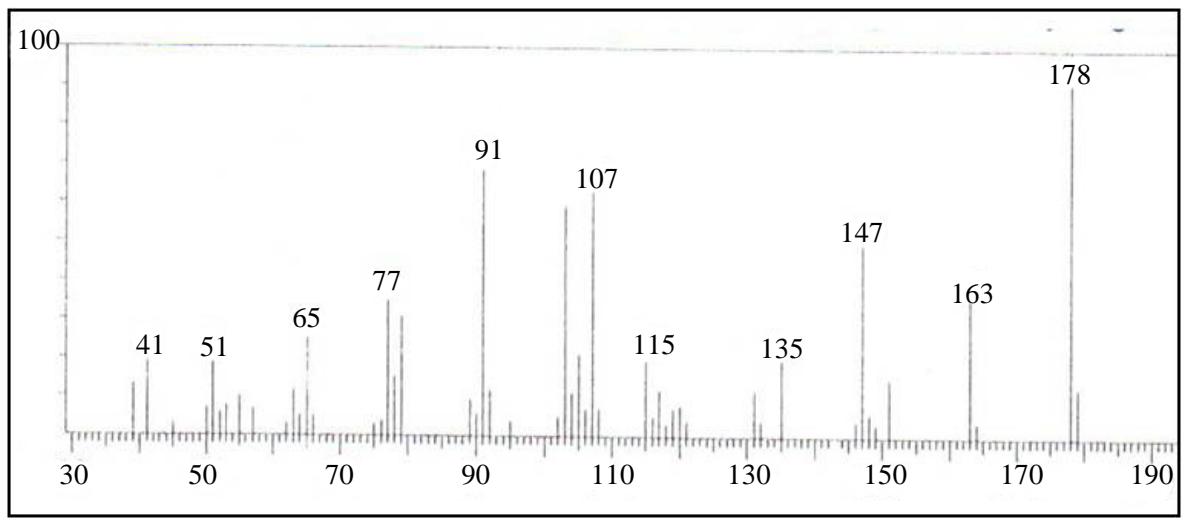

(c)

Figure 1. Gas chromatograms of essential oil extracted by hydro distillation from leaves of South-Darfur (a), Kennana (b) and Silate-Egyptian (c) accessions. 
essential oil was received in a special container and then stored in sealed vials at $+4^{\circ} \mathrm{C}$ until tested and analyzed. The essential oil was calculated as a percentage based on dried weight.

\subsection{Gas Chromatography-Mass Spectrometry Analysis}

The essential oil constituents’ analysis was carried out at General Administration of Criminal Evidence, Sudan, Khartoum. To identify the constituents of essential oil extracted from the leaves of the 3 accessions, GC-MS Instrument (QP 2010) equipped with a capillary column (20 to $30 \mathrm{~m} \times 0.2 \mathrm{~mm}$; film thickness $0.5 \mathrm{Mm}$ ) was used. Helium (99.999\%) was used as a carrier gas with a flow rate of $1 \mathrm{ml} / \mathrm{min}$. Essential oil solution (3 $\mathrm{ml})$ in methanol was injected using split mode $1: 100$. The oven temperature was increased between $80^{\circ} \mathrm{C}-290^{\circ} \mathrm{C}$. The oil constituents were identified by comparison of their retention time (RT) with the mass spectral library of the GC-MS data software system (Wiley-7 spectral database).

\section{Results and Discussion}

The essential oil of the three accessions primarily had light yellowish colored oil. The stem oil content for all 3 accessions was zero. The results revealed that the essential oils content varied with a range of $0.29 \%$ to $0.33 \%$ for flowers and $0.32 \%$ to $0.48 \%$ for leaves. As usual, the content of essential oils was higher in leaves than in flowers. The Silate-Egyptian accession had the lowest essential oil content obtained from leaves and flowers. However, South Darfur accession had the highest oil content but did not significantly differ from Kennana accession. In a study carried out in Iran [18] the content of the essential oils hydro distilled from aerial parts of $O$. basilicum was $0.2 \%$. Similarly, under field conditions, [19] stated that the essential oil content was higher in leaves $(0.75 \%)$ than in flowers $(0.69 \%)$.

Analysis of essential oil hydro-distilled from leaves by GC-MS revealed that terpenes are the most predominant constituents of the essential oil from the examined basil accessions. The major terpenes present are linalool, eugenol, and germacrene-D (Figure 1). Methyl eugenol was the major constituent of the essential oil of Kennana accession. While the major constituent of essential oil of South-Darfur and Silate-Egyptian accessions were germacerene-D and linalool, respectively. In other studies, linalool, eugenol and germacrene were also found as major constituents of the basil oil with varied percentages [7] [14]. This variation may be attributed to environmental and physiological factors. On the contrary, the constituents of essential oil hydro distilled from the aerial parts of Ocimum basilicum from Northern Ethiopia was examined by GC-MS [20]. The major constituents identified were copaene (25.5\%), p-menth-2-en-1-ol (7.7\%), eugenylacetae (4.8\%). These results confirm the classification of $O$. basilicum from Sudan as linalool and eugenol chemotype reported by [14].

\section{Conclusion}

The assessment of the essential oils obtained from the aerial parts of three accessions of basil Ocimum basilicum L. and its analysis in this study, revealed that, the two Sudanese accessions "Kennana” and "South-Darfur" gave the highest oil content in comparison to the introduced one "Egyptian accession". On the other hand, Methyl eugenol was the major constituent of the essential oil of "Kennana” basil accession. While the major constituent of essential oil of South-Darfur, and Silate-Egyptian basil accessions, were germacerene and linalool, respectively.

\section{References}

[1] Khalid, H. Abdalla, W.E., Abdelgadir, H., Opatz, T. and Efferth, T. (2012) Gems from Traditional North-African Medicine: Medicinal and Aromatic Plants from Sudan. Natural Products and Bioprospecting, 2, 92-103. http://dx.doi.org/10.1007/s13659-012-0015-2

[2] WHO (2003) Traditional Medicine. Fact Sheet Nr. 134. http://www.who.int/mediacentre/factsheets/2003/fs134/en/

[3] Hedge, C. (1992) A Global Survey of the Biogeography of the Labiatae. In: Harley, R.M. and Reynolds, T., Eds., Advances in Labiatae Science, Royal Botanic Gardens, Kew, 7-17.

[4] Paton, A. Harley, R.M. and Harley, M.M. (1999) Ocimum: An Overview of Relationships and Classification. In: Holm, Y. and Hiltunen, R., Eds., Medicinal and Aromatic Plants_Industrial Profiles, Harwood Academic, Amsterdam, 1-38.

[5] Hossein, G.T. (2011) Review to Basil Medicinal Plant. International Journal of Agronomy and Plant Production, 2, $5-9$. 
[6] Sugumaran, M. and Vetrichelvan, T. (2008) Aromatherapy: The Power of Scent. Ethnobotanical Leaflets, 12, 591-98.

[7] Nurzynska-Wierda, R., Bogucka-Kocka, A. Kowalski, R. and Borowski, B. (2012) Changes in the Chemical Composition of the Essential Oil of Sweet Basil (Ocimum basilicum L.) Depending on the Plant Growth Stages. Chemija, 23, 216-222.

[8] Lorenzi, H. and Matos, F.J.A. (2002) Plantasmedicinais no Brasil: nativas e exóticas. Instituto Plantarum, Nova Odessa, 252.

[9] Chiang, L.C., Cheng, P.W. and Chiang, W. (2005) Antiviral Activities of Extracts and Selected Pure Constituents of Ocimum basilicum. Journal of Clinical and Experimental Pharmacology and Physiology, 32, 811-816. http://dx.doi.org/10.1111/j.1440-1681.2005.04270.x

[10] De Almeida, I., Alviano, D.S. and Vieira, D.P. (2007)Antigiardial Activity of Ocimum basilicum Essential Oil. Parasitology Research, 101, 443-452. http://dx.doi.org/10.1007/s00436-007-0502-2

[11] Manosroi, J., Dhumtanom, P. and Manosroi, A. (2006) Anti-Proliferative Activity of Essential Oil Extracted from Thai Medicinal Plants on KB and P388 Cell Lines. Cancer Letters, 235, 114-120. http://dx.doi.org/10.1016/j.canlet.2005.04.021

[12] Tohti, I., Tursun, M., Umar, A, Turdi, S., Imin, H. and Moore, N. (2006) Aqueous Extracts of Ocimum basilicum L. (Sweet Basil) Decrease Platelet Aggregation Induced by ADP and Thrombin in Vitro and Rats Arterio-Venous Shunt Thrombosis in Vivo. Thrombosis Research, 118, 73-79. http://dx.doi.org/10.1016/j.thromres.2005.12.011

[13] Saha, S., Dhar, T.N., Sengupta, C. and Ghosh, P.D. (2013) Biological Activities of Essential Oils and Methanol Extracts of Five Ocimum Species against Pathogenic Bacteria. Czech Journal of Food Sciences, 31, 194-202.

[14] Azhari, H.N., Elhassein, S.A., Osman, N.A. and Abduelrahman, H.N. (2009) Repellent Activities of the Essential Oils of Four Sudanese Accessions of Basil (Ocimum basilicum L.) against Anopheles Mosquito. Journal of Applied Sciences, 9, 2645-2648. http://dx.doi.org/10.3923/jas.2009.2645.2648

[15] Alizadeh, A. (2013) Essential Oil Constituents, Antioxidant and Antimicrobial Activities of Salvia virgate Jacq. from Iran. Journal of Essential Oil Bearing Plants, 16, 172-182. http://dx.doi.org/10.1080/0972060X.2013.793974

[16] Al-Qudah, M.A., Al-Jaber, H.I., Abu Zarga, M.H. and Abu Orabi, S.T. (2014) Flavonoid and Phenolic Compounds from Salvia palaestina L. Growing Wild in Jordan and Their Antioxidant Activities.Phytochemistry, 99, 115-120. http://dx.doi.org/10.1016/j.phytochem.2014.01.001

[17] Usano-Alemany, J., Pala-Paul, J., Rodriguez, M.S. and Herraiz Penalver, D. (2014) Chemical Description and Essential Oil Yield Variability of Different Accessions of Salvia lavandulifolia. Natural Product Community, 9, 273-276.

[18] Sajjadi, S.E. (2006) Analysis of the Essential Oils of Two Cultivated Basil (Ocimum basilicum) from Iran. DARU, 14, 128-130.

[19] Asadollahi, A., Mirza, M., Abbaszadeh, B., Azizpour, S. and Keshavarzi, A. (2013) Comparison of Essential Oil from Leaves and Inflorescence of Three Basil (Ocimum basilicum L.) Populations under Drought Stress. International Journal of Agronomy and Plant Production (Online), 4, 2764-2767.

[20] Unnithan, C.R., Dagnaw, W., Undrala, S. and Subban, R. (2013) Chemical Composition and Antibacterial Activity of Essential oil of Ocimum basilicum of Northern Ethiopia. International Research Journal of Biological Sciences, 2, 1-4. 